\section{Omfattende om kvalitet}

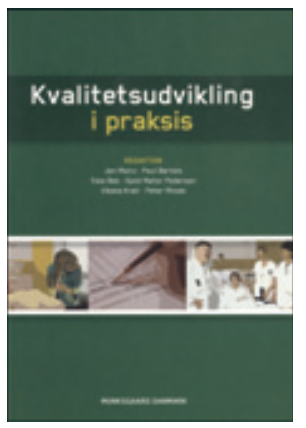

Jan Mainz, Paul Bartels, Tore Bek et al, red. Kvalitetsudvikling i praksis

431 s, tab, ill. København: Munksgaard

Danmark, 2011. Pris DKK 348

ISBN 978-87-628-0714-3

Målgruppen er alle faggrupper i helsevesenet, i tillegg til politikere og administratorer. Målet er å beskrive det teoretiske og praktiske grunnlaget for moderne kvalitetsutvikling i helsevesenet på et kunnskapsbasert grunnlag. En av styrkene er at de 21 kapitlene er bygd opp omkring et innledende tilfelle som illustrerer kapitlets problemstilling. Det fungerer godt i mange av kapitlene, gjør stoffet mindre tørt og letter tilegnelsen av teori og metode. Forfatterne har også en ambisjon om å dokumentere at implementeringen av den omtalte metoden, aktivitet e.l. har effekt på kvaliteten i helsevesenet. Denne ambisjonen klarer de bare delvis å gjennomføre. Det er ikke rart, i et felt der intervensjonene er så sammensatte, der de påvirker hverandre på et ofte uforutsigbart vis, og der vi i stor grad savner «a magic bullet».

I en kort innledende del fokuserer forfatterne på begreper, terminologi og på hvordan kvalitet og kvalitetsutvikling kan defineres og bare delvis avgrenses fra forskning og medisinsk teknologivurdering.

Det er særlige forventninger til en dansk bok om kvalitetsutvikling. Danskene er langt fremme internasjonalt i slikt arbeid, ikke minst i allmennmedisin. Dessverre finner jeg få spor av dette her. Teksten er, som de fleste tekster om kvalitet, dominert av sykehusenes behov og tenkemåter. Forfatterne omtaler verken Maturity Matrix, praksiskonsulentordningen som Norge har adoptert fra Danmark, eller Norsk elektronisk legehåndbok, som nå er kjøpt av danskene. Andre mangler er et magert stikkordregister og et pussig ukritisk språk. I Norge ville begreper som «kronikere», «kronikeromsorg» etc. ført til diskusjoner: Det finnes ikke kronikere, bare folk med kroniske tilstander eller problemer. Folk er folk, ikke diabetikere eller sinnssyke, men folk med diabetes eller psykiske lidelser.

Mange av kapitlene er nyttige og gir ny innsikt, eksempelvis kapitlene om kliniske epidemiologiske aspekter i kvalitetsutvikling, indikatormonitorering, kvalitetsutvikling og incitamenter (P4P) og offentliggjøring av informasjon om kvalitet. Men jeg undrer meg. Dette feltet er i rivende utvikling. I min verden, når jeg skal oppdatere meg om noe hyperaktuelt, går jeg heller på nettet, til litteraturen eller til kloke kolleger for å finne ut hvordan ting henger sammen. Det er et fortjenstfullt og stort prosjekt å lage en lærebok om et felt som endrer seg så raskt, men er det vel anvendt tid? Vi risikerer at i morgen er alt revidert. Uansett, boken vil være et av mine viktige oppslagsverk i arbeidet med kvalitetsutvikling i praksis, men neppe den eneste kilden til innsikt, slik verden nå er blitt.

\section{Janecke Thesen}

KUP (Allmennmedisinsk utvalg for kvalitet og pasientsikkerhet) Bergen

\section{Ikke godt nok om forløsningskunst}

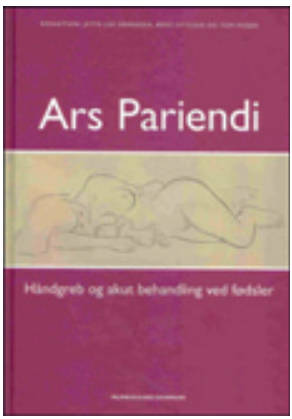

Jette Led Sørensen, Bent Ottesen,

Tom Weber, red.

Ars pariendi

Håndgreb og akut behandling ved fødsler.

256 s, tab, ill. København: Munksgaard

Danmark, 2011. Pris DKK 428

ISBN 978-87-628-0795-2

Dyre Trolle (1914-2002), overlege på Rigshospitalet i København og professor ved København universitet, ga i 1964 ut en håndbok i praktisk fødselshjelp, beregnet på å kunne bæres i frakkelommen. Den var detaljert i sin beskrivelse av obstetriske håndgrep. Teksten vitnet om forfatterens egen erfaring. Boken kom i ny utgave i 1967, og denne er lagt ut i fulltekst på nettet (1). Den var ikke beregnet for studenter eller allmennleger, men «et vademecum for alle, der aktivt beskæftiger sig med fødselshjælp» (vademecum = detaljert håndbok). Siden er det kommet mange lærebøker i fødselshjelp, men få med dette målet. Det var derfor med stor glede og spenning jeg begynte på en ny dansk håndbok med samme navn, redigert av tre aktive kolleger og med dagens utgangspunkt for fødselshjelpen.

Temaet fortjener en egen bok. Redaktørene og kapittelforfatterne skal roses for å restituere konseptet forløsningskunst og for å ta håndgrep alvorlig som en nødvendig del av fødselshjelp. Mange nye bøker omhandler kun enkel vakuumforløsning, keisersnitt og epidemiologi. Boken har 22 kapitler og 28 forfattere, en firedel er jordmødre. Forløsning er tverrfaglig, boken et fellesprodukt, og omtale av hvordan samarbeid og kommunikasjon skal foregå på fødestuen, hører hjemme i en utgivelse som denne. Temavalget er bredt og går utenfor forløsningskunsten. Hvorfor kapitlene om preeklampsi og de fysiologiske forandringene i svangerskapet hører med, har jeg, uansett hvor viktige temaene er, vanskelig for å forstå.

Med så mange forfattere kan ikke fremstillingen unngå å bli ujevn. Fordi så mange temaer utenfor kjerneområdet er tatt med, er teksten hele veien så kortfattet at det ikke kan bli tale om det vademekum som Trolle la opp til. Noen kapitler er sammenfattende og gode, f.eks. om ultralydskanning på fødegangen og blødning $i$ tredje trimester. Noen er så detaljerte at de er et vademekum, kapitlet om blodprøver fra fosteret under fødselen er et eksempel. Her er det praktiske tatt på alvor.

Svakhetene er imidlertid for tydelige i flere av kapitlene om forløsning, som skulle være hovedtemaet. Kapitlene om sete- og tvillingfødsel mangler mye på å være et vademekum. Når forfatterne påstår at det er veldokumentert at planlagt vaginal fødsel er farligere for barnet, tar de ikke hensyn til den kritikk Term Breech Trial har fått de senere årene. Uttrykk som «anbefales på nogle danske fødeafdelinger», «anbefales på flere danske fødeafdelinger» og «anbefales på de fleste danske fødeafdelinger» har ikke mye å gjøre med det de fleste av oss oppfatter som kunnskapsbasert fødselshjelp. Verre er det at forfatterne mangler et overordnet syn på og fremstilling av fødselens forløp med utgangspunkt i kunnskap om fødselsveienes og fosterets anatomi. Når det om hodet ved setefødsel heter at det skal være flektert, gir det seg selv ved kunnskap om fødselsprosessen, bekkenets diameter og hodets diameter, og huskeregler som «flection means friend «og «extension means enemy» blir pinlige.

Forfatterne avslutter hvert kapittel med en kortfattet litteraturoversikt, hvor bøkene og artiklene gjennomgående er svært relevante. Problemet er at det pga. manglende referanser i teksten ikke er mulig å se hvor dokumentasjonen for råd og påstander kommer fra. Et lite tillitvekkende eksempel er innledningen på kapitlet om keisersnitt, der uttrykket sectio caesarea tilskrives at «Kejser Gaius Julius Caesar» kom til verden på denne måten. Det er en detalj at Cæsar ikke var keiser. Mer beklagelig er det at, i listen over supplerende litteratur ved 